\title{
Analysis on Education Provision Policy in Frontier, Outermost, and Underdeveloped Regions to Improve National Security in Sebatik Island, Indonesia
}

\author{
Asri Nur Aina ${ }^{1 *}$, Siswidyanto ${ }^{2}$, Ainul Hayat ${ }^{2}$ \\ ${ }_{1}^{1}$ Postgraduate Program of Public Administration, Faculty of Administration Science, \\ Universitas Brawijaya, Jl. MT. Haryono No. 163, Malang, 65145, East Java, Indonesia. \\ ${ }^{2}$ Department of Public Administration, Faculty of Administration Science, Universitas \\ Brawijaya, Jl. MT. Haryono No. 163, Malang, 65145, East Java, Indonesia.
}

Received: 2021-02-13; Accepted: 2021-03-27; Published: 2021-04-30

\begin{abstract}
This article aimed to analyze the Government Policy in the process of implementing education to improve National Security at the Sebatik Island of Nunukan Regency. The author analyzed using Bardach's Eightfold path to more effective problem solving which consists of defining the problem, assembling the evidence, constructing the alternatives, selecting the criteria, projecting the outcomes, confronting the trade-offs, deciding, and telling the story. This is a descriptive-type study with a qualitative approach. Study results shows that in Nunukan Regency, especially Sebatik Island that is considered as a Frontier, Outermost, and Underdeveloped region, which also lies at the border between Malaysia and Indonesia-haven't been optimally carrying out policies on education implementation for improving national security. This was also proven by the number of schools that lack the necessary facilities and infrastructures, in addition to the curriculum that has yet to instil national security strengthening in schools and the lack of routine for nationalism-related activities given by the local government. Therefore, the local government should synergize with other parties, such as the Indonesian Army and education communities to improve national security in Sebatik Island while also strengthen the students' sense of nationalism through accommodating school subjects on Indonesian nationality and culture.
\end{abstract}

Keywords: Education Policies; Frontier Region; Outermost Region; Underdeveloped Region; National Security

How to Cite: Aina, A. N., Siswidyanto, S., \& Hayat, A. (2021). Analysis on Education Provision Policy in Frontier, Outermost, and Underdeveloped Regions to Improve National Security in Sebatik Island, Indonesia. Journal of Contemporary Governance and Public Policy, 2(1), 1-12. https://doi.org/10.46507/jcgpp.v2i1.34.

Permalink/DOI: https://doi.org/10.46507/jcgpp.v2i1.34 


\section{Introduction}

Based on publications from the Ministry of Home Affairs published in the 2018 Statistics Book of Indonesia, Indonesia has 16.056 islands in 2017. This number reduced by 1448 islands from the previous year which accounted for 17.504 islands. As an archipelagic country, Indonesia shares direct borders with 10 (ten) other countries. The borders in land area are shared with three countries, which are Malaysia, Papua New Guinea, and Timor-Leste. Indonesian sea area bordered with 10 countries, namely India, Malaysia, Singapore, Thailand, Vietnam, the Phillipines, Republic of Palau, Australia, Timor-Leste, and Papua New Guinea (Indonesia, 2018).

One important aspect in geopolitics is country borders where history has proven various intercountry and international problems due to border disputes. Basically, the term "Border" has two definition: Boundaries and Frontiers. In the context of Boundaries, borders are the dividing lines of international area while in the context of Frontiers, borders refer to lanes or zones stretching and separating two regions of countries (Rantau Itasari, 2020).

Border area is a strategic territory due to its position being adjacent to neighboring country(ies), making border areas' development and progress the symbol, gateway, and pride of Indonesia in the international scale. However, the reality is that border areas in this country are still identified as the frontier, outermost, and underdeveloped regions. This means, it's undeniable that border areas are still becoming serious concern for this country.

In the Presidential Regulation No. 131 of 2015, underdeveloped regions are defined as regions with underdeveloped areas and population compared to others on a national scale. Based on the regulation, a region is considered to be an underdeveloped region if they fulfill certain criteria, comprising of people's economy, human resources, facilities and infrastructures, regional financial capacity, accessibility, and regional characteristics.

As established by the Presidential Regulation No. 131 of 2015, there are currently 122 underdeveloped regions. Reflecting on those figures, the government should have implemented strategic moves for carrying out improvements in underdeveloped regions and borders. Broadly speaking, the existing problems in border areas comprise of three aspects: regional socio-economy, socio-economy, and defense and security. National defense and security, especially in border areas, are vulnerable to threats and influences from neighboring country(ies). Thus, it is unquestionable that the countless problems that lie in border areas become an alternative to subside the sense of nationalism of people living in border areas (Rantau Itasari, 2020).

One precise strategy which aims to develop a nation and country is to place education development as the leading sector. As a result, almost all countries position education development as their main priority in national development programs. The key to a country's success in development is competent and quality human resources which are the products of education (Asri, 2016). Also, people's quality will determine the success of development and education is the key to achieve competent people (Kurniawan \& Managi, 2018).

A number of concrete issues which often occur in border areas are difficulties in communication and the 
scarcity of the means to assist teaching-learning process which hinder the process of building standard education facilities and providing educators in frontier, outermost, and underdeveloped regions regions and border areas. Currently, border areas are still categorized as isolated, remote, and underdeveloped regions, which also apply to their education sector. Education in border areas is still relatively lower when compared to other regions due to the distribution of facilities and infrastructures not reaching villages which are farther located from each other (Suciati \& Ariningsih, 2016). This, of course, is contrasting with what Coleman stated in Mujahidun (2016) which explained that the concept of distribution consists of passive distribution, i.e. distributions which emphasize more on the equality of opportunity to enroll in school, while active distribution means equal opportunity for enrolled students to achieve the highest education result. Based on this understanding, education distribution becomes broader which consists of things, such as equality of access, equality of survival, equality of output, and equality of outcome.

Several great challenges in Sebatik Island are the many Indonesian workers' (TKI; Tenaga Kerja Indonesia) children who go to school in the island because they are denied from going to school in Malaysia, where Malaysia often becomes the main target country for TKI. In addition, the problem existing in those borders today is the lack of literatures which introduce Indonesian cultures to the schoolchildren in Sebatik Island, resulting to more dominant cultural influences from the neighboring country, i.e. Malaysia.

The amount of educationrelated problems, which include inadequate education will eventually impact national security because the two share reciprocal relationship, both positively and negatively (Joshua, Ibietan, \& Azuh, 2016). Unsupportive educational situation and condition will negatively impact conditions in border areas and have the possibility to further threaten national sovereignty (Abdi, 2018). As a consequence, the government's challenge is to find out ways to integrate people's security as a core in the process of planning and implementing border area developments in order to improve human-development-based national security. If the developments of border areas disregard people's security, what would happen is that the sense of nationalism of people living in those areas gradually diminishes and ceases to exist because they feel neglected by the government. Their trust towards their government will also decrease, which in turn disrupts national security that affects the unity of nation. The government must focus on people's education and welfare when developing border areas (Rani, 2012).

Sebatik Island is one of the districts in Nunukan Regency, North Kalimantan. This island is one of the frontier, outermost, and underdeveloped regions which is the main priority for development because it is directly adjacent to a neighboring country, namely Malaysia. Sebatik Island, which is very close to Malaysia, is very vulnerable to various threats such as threats from the defense and security sector, economic threats and ideological threats. Apart from that, narcotics is still the biggest threat on Sebatik Island. Its location is very close and there is a lack of supervision so that many smugglers use the rat route to enter drugs into 
Indonesian areas. Some of the national security problems faced by the community occur because one of the factors is the low quality of human resources in the Border area (Siregar, 2008).

The current conditions at the border are relevant for reviewing regulations, policies, programs, and budgets from the central or regional governments, especially in the education sector, whether the current conditions have met the principle of availability, the principle of opportunity to obtain, the principle of acceptance and the principle of adjustment in the region (Itasari, 2020).

Based on the description above, this article is important to conduct a more in-depth analysis of educational policies and programs to improve National Security on Sebatik Island, Nunukan Regency.

\section{Research Methods}

One of the causes for the low quality of human resources is determined by education. Education on Sebatik Island is currently still facing several major challenges including a lack of educators both in quantity and quality, lack of educational infrastructure, unavailability of public transportation to make it easier for students to go to school, a lack of compatibility between the curriculum and the needs of the people on Sebatik Island, and many of them. underprivileged children from Indonesian Migrant Workers (TKI) families who go to school on Sebatik Island due to being refused school in Malaysia (Rosliana, W, Lutfie, Hidayah, \& Aziza, 2015). Outermost, and Underdeveloped (3T) regions in order to improve the national security. This study was carried out in Sebatik Island of Nunukan Regency in North Kalimantan. This study focused on policies of education provision from the perspective of policies on education implementation, government programs, education curriculum, and education facilities and infrastructures. The author conducted policy analyses using an approach by Bardach (Ainul, 2018) which was the Eightfold path to more effective problem solving, which comprise of defining the problem, assembling the evidence, constructing the alternatives, selecting the criteria, projecting the outcomes, confronting the trade-offs, deciding, and telling the story. Data were sourced from primary and secondary data. Primary data were obtained through interviews conducted on 12 informants which consist of government officials of Nunukan Regency, member of Regional People's Representative Council (DPRD; Dewan Perwakilan Rakyat Daerah) of Nunukan Regency, headmasters of elementary schools in Sebatik Island, community figures, and the Chairman of Community Council of Sebatik Island. Meanwhile, secondary data were acquired from documents. Data collections were done through observations, interviews, and documentations. This study used Miles and Huberman data analysis which was performed cyclically and was separated into three steps: Data codification, data display, and conclusion drawing or verifying (Miles \& Huberman, 2007).

\section{Results and Discussion}

Based on focus of the study, there are three things which can be highlighted in the process of education provision, which were: regulation for education implementation as the reference for the process of implementing education in Sebatik Island, learning curricula, and facilities and 
infrastructures which support the process of implementing education.

\section{Regulation for Education Implementation}

The implementation of policy on regional autonomy based on Law No. 32 of 2004 decide on a policy independently where the authority once belonged to the central government is now handed down to regions, in this case provinces and regencies/municipalities. In attempt to improve the qualities of human resource, global competitiveness, and nation's intellectual capacity, the government of Nunukan Regency have formulated Regional Law No. 05 of 2012 concerning the management and implementation of education to achieve proper education and guarantee equal opportunity of quality education for people in Nunukan Regency. Management for education-contained in the Regional Law No. 05 of 2012-serves a purpose to: 1) Guarantee public access for sufficient, equal, and affordable education. 2) Guarantee competitiveness and quality of education and its releance with society's needs and/or conditions. 3) Guarantee the effectiveness and accountability of education management. However, the regulation does not have special treatment for border areas. This is because there is no central government regulation regulating the management and implementation of special education in border areas. This is also done by stakeholders in Nunukan Regency so that the efforts carried out are only for the cultivation of national insight orally.

The need for special policies in border areas was also expressed by (Itasari, 2020) in her research which explained that one of the obstacles in border areas is geographical constraints and natural contours in the form of forests which cause a lack of access to education so that affordability is low. Although there have been several efforts by the central government and local governments to resolve these problems, there has not been any focus on the quality and quantity aspects of advice and infrastructure. Itasari, (2020) considers that there is a current government policy that wants to build from the border and outermost areas, education should be a priority for fulfilling the right to education for people on the border. Based on the government's wishes, it is deemed necessary to have a study to obtain an overview of the politics of law and state policies as well as a comprehensive analysis of policies, programs, activities and funding in fulfilling the right to education, both primary and secondary education in border areas.

\section{Learning Curricula}

Most of the schools on Sebatik Island have implemented a curriculum regulated directly by the central government, namely the curriculum contained in the Regulation of the Minister of Education and Culture No. 57 of 2014 concerning the 2013 Curriculum for Elementary School / Madrasah Ibtidaiyah and No. 58 of 2014 concerning the 2013 Junior High School / Madrasah Tsanawiyah Curriculum. This regulation has attached a syllabus which technically details the subject points that the teacher will teach to students. In the context of improving national security or the context of national security and resilience, the 2013 curriculum has been contained in education and citizenship subjects which contain Pancasila values, the role of the region in the framework of the Republic of Indonesia, how to defend independence and others. 
Currently on Sebatik Island, there are still many students who are not fully familiar with Pancasila and have not studied the meaning of citizenship. This can be seen from the number of students who find it difficult to use Indonesian well, still tend to use the language and currency from Malaysia which symbolically shows that there is dependence on neighboring countries, even at the elementary school level, there are still many students who have not memorized the Indonesia Raya national anthem as well as Pancasila. This proves that the values in the civic education subject have not been embedded in students on Sebatik Island.

Yanti \& Nini (2018) in their research also showed the results that students' understanding of the history of the nation's struggle was still minimal. One sample in Sebatik Island is SD 01 Sebatik Tengah, which is located very close to stake 3 or the border stake between Malaysia and Indonesia. This proves the lack of national insight among students in border areas. Agung, (2012) explained the need for planting a national insight into his research which revealed that there needs to be attention and handling of the cultivation of the value of national insight in border areas so that it becomes one of the deterrents of all actions that can endanger the integrity of the Indonesian state. Agung, (2012) also explained that the condition of students national insight is very easily influenced by foreign elements, therefore it is necessary to spread and cultivate national insight to students or students at the border.

The importance of national insight can be an input for the government in making policies related to the curriculum. Ro, (2020) explains that policy makers basically have the authority to define and develop curricula. They can organize teaching to define specific goals, content, learning processes, and assessments. The government as the policy maker in the Sebatik Island area, of course, has the authority to develop a curriculum based on the needs of the region. Lambert \& Penney (2020) explains that basically in making curriculum, it is necessary to pay more attention to the social context in which the curriculum is made. The research of Joshua et al., (2016) also reveals that the importance of the curriculum also has an impact on national security in Nigeria. The large number of unemployed created is the impact of damaged education and curricula.

\section{Education Facilities and Infrastructures}

Facilities and infrastructures for education are two pillars for the process of implementing education. The Law of Republic of Indonesia No. 20 of 2003 stated that every formal and non-formal educational unit should provide the facilities and infrastructures which fulfill the needs of education according to the growth and development of learners' physical, intellectual, social, emotional, and spiritual potential. In addition, Government Regulation of the Republic of Indonesia No 19 of 2005 regarding National Standard of Education elaborated that every educational unit should have the necessary education facilities and infrastructures comprising furnitures, education equipments, books and other learning sources, consumables, and necessary supplies to support steady and sustainable learning process. Other facilities and infrastructures also consist of land, classrooms, head office, teacher's office, library, laboratory, canteen, gymnasium, prayer room, outdoor areas, and other spaces required to 
support orderly and continuous learning process.

Based on the study result in Sebatik Island, there are still many inadequate facilities and infrastructures. This was confirmed by the Headmaster of Public Junior High School 1 of North Sebatik during the process of interview who explained that currently, there are shortage of classes and equipments in classes which hinder the process of implementing education. In spite of this, the school keeps on maximizing learning and teaching processes in order to make sure the students receive their rights. This was also proven by the data provided by the Education Agency of Nunukan Regency, which was imbalance between the number of study groups and classrooms, in addition to laboratories and libraries which are not proportional to the number of schools. The following is data of the schools in Sebatik Island in table 1 and table 2 .

Table 1. Data of facilities and infrastructures of public schools in Sebatik Island Source: Education Agency of Nunukan Regency, 2019

\begin{tabular}{lcccccc}
\hline No Districts & $\begin{array}{c}\text { Number } \\
\text { Of } \\
\text { Schools }\end{array}$ & $\begin{array}{c}\text { Number Number } \\
\text { Of }\end{array}$ & $\begin{array}{c}\text { Nudents Groups } \\
\text { of Study }\end{array}$ & $\begin{array}{c}\text { Numbr Of } \\
\text { Classrooms Laboratories }\end{array}$ & $\begin{array}{c}\text { Number of } \\
\text { Libraries }\end{array}$ \\
\hline 1 Sebatik & 4 & 742 & 27 & 26 & 2 & 4 \\
\hline 2 East Sebatik & 3 & 967 & 42 & 29 & 0 & 3 \\
\hline 3 West Sebatik & 8 & 1592 & 65 & 63 & 3 & 3 \\
\hline 4 North Sebatik & 3 & 1061 & 43 & 33 & 2 & 5 \\
\hline 5 Central Sebatik & 8 & 1211 & 56 & 57 & $\mathbf{1 0}$ & $\mathbf{2 0}$ \\
\hline TOTAL & $\mathbf{2 6}$ & $\mathbf{5 5 7 3}$ & $\mathbf{2 3 3}$ & $\mathbf{2 0 8}$ & \\
\hline
\end{tabular}

Table 2. Data of facilities and infrastructures of private schools in Sebatik Island Source: Education Agency of Nunukan Regency, 2019

\begin{tabular}{lcccccc}
\hline No Districts & $\begin{array}{c}\text { Number Number Number } \\
\text { Of } \\
\text { Schools }\end{array}$ & $\begin{array}{c}\text { Of } \\
\text { Ofudents } \\
\text { of Study }\end{array}$ & $\begin{array}{c}\text { Number Of } \\
\text { Classrooms Laboratories }\end{array}$ & $\begin{array}{c}\text { Number of } \\
\text { Libraries }\end{array}$ \\
\hline 1 Sebatik & 4 & 464 & 26 & 23 & 1 & 2 \\
\hline 2 East Sebatik & 9 & 1480 & 71 & 60 & 2 & 4 \\
\hline 3 West Sebatik & 2 & 116 & 12 & 9 & 0 & 1 \\
\hline 4 North Sebatik & 2 & 331 & 13 & 6 & 0 & 0 \\
\hline 5 Central Sebatik & 1 & 43 & 6 & 6 & $\mathbf{3}$ & $\mathbf{9}$ \\
\hline TOTAL & $\mathbf{1 8}$ & $\mathbf{2 4 3 4}$ & $\mathbf{1 2 8}$ & $\mathbf{1 0 4}$ & \\
\hline
\end{tabular}

In fulfilling the facilities and infrastructure, it can be concluded that the current condition of schools on Sebatik Island is still lacking 
school facilities such as classrooms, teaching aids and class facilities to support the implementation of education. The importance of facilities and infrastructure needs to be the attention of the local government in order to focus on the development of facilities and infrastructure. In the context of national security, especially in human security, one of the coverage that must be fulfilled is access to education services. Therefore, the government is obliged to provide access and proper education to border communities to improve the national security of the local community.

Uline \& Tschannen-Moran, (2008) laid the foundation for the relationship between the physical environment of the school and student achievement, from the findings in a number of studies showing that there is a close relationship between student achievement and the physical quality of the school. Old building conditions also greatly affect student achievement. In contrast to the results of research by Gronberg, Jansen, \& Taylor, (2011) which explains that although their research suggests equal access to educational facilities does not mean that this affects student achievement. His research evidence suggests that performance improvements will be lower as the cost of resources is shifted to maintenance. While no doubt students and teachers will be happy spending their days in a modern school building with many facilities, there is no evidence that students learn more in such an environment.

\section{Policy Recommendations}

The implementation of public policy requires a model to be the solution of a problem. Basically there is no competition or contestation process among the model of policy implementation, because the more relevant issue is the suitability of implementation with its own policies (Adler \& Seligman, 2016).

Based on the existing problems, the author tries to build a top-down model to improve national security in Sebatik Island. The important features of top-down approach are that is starts with a government policy decision and to answer the questions :

1. How the consistency of the actions of the executive officer and the target group towards the policy decision.

2. How can the goals be achieved?

3. What are the main factors that influence policy output and impact?

4. How was the policy reformulated over time on the basis of experience? (Sabatier, 1986).

Based on the study result, plenty of matters still require further attention, especially in the process of implementing education in Sebatik Island so that the students are able to experience educational facilities like any other school elsewhere. Seeing the current conditions in Sebatik Island-the abundant aids and products from Malaysia, with the addition of the prevalent uses of Malaysian Ringgit as currencyimprovements need to be made in order for the students in Sebatik Island to also receive the proper facilities, lest they compare what was given by the Malaysian Government and the Indonesian Government. Therefore, the author made attempts to come up with policy recommendations in the form of education implementation model. The following is the model proposed by the author in figure 1. 


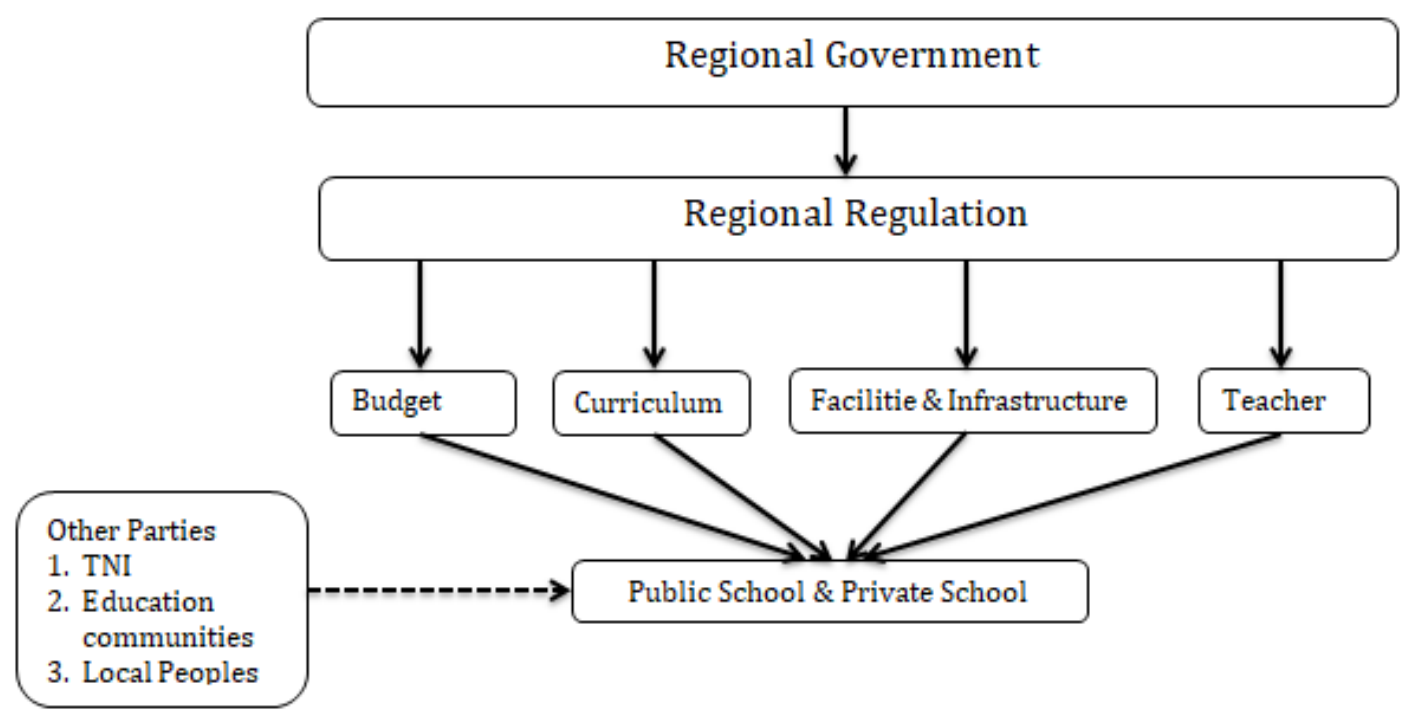

Figure 1. Reccomendation model to improve national security in Sebatik Island Source: Processed by the Authors (2021)

In this model, there is no difference in regard to the attention given from the government to both public and private schools. Specifically for the curriculum, the government does not provide a new form of curriculum because the curriculum has been regulated by the central government, it's just that in the context of this curriculum local governments can emphasize nationalbased character education. The role of the regional government must be more active in increasing national security because today there is still no central regulation that addresses education at national borders.

The author also suggest involving several actors, such as the Indonesian National Armed Force (TNI; Tentara Nasional Indonesia), education communities, and local people to keep on overseeing and improving national security in Sebatik Island. One form of oversight is to hold nationalism-related activities which involve all students in the border area in a continuous manner to uphold their sense of nationalism. In addition, the paramount roles of teachers are expected to continuously slip in nationalism values in every subjects taught or to instil appreciation for Indonesian Rupiah more in every local subject (mulok; muatan lokal) in order to minimalize the use of Malaysian Ringgit in Sebatik Island.

\section{Conclusion}

National security is very important in border areas through the provision of quality education, several technical steps that can be taken, namely:

1. The central government forms a regulation related to education in border areas which becomes a reference for local governments.

2. Local governments issue regulations related to the implementation and management of education in border areas that are adjusted to central government regulations

3. The local government regulates an additional curriculum (local content lessons based on local needs) which can be adapted to the curriculum from Permendikbud No. 57 and 58 concerning the basic education curriculum. The 
additional content that can be used as a local content subject is lessons about national insight, the history of the struggle of the Indonesian nation, the patriarch of the country, defending the country and others.

4. Local governments provide adequate facilities and infrastructure so that education at the border is not left behind from education in urban areas or in neighboring countries. The current shortcomings are regional facilities such as public transportation, school facilities such as classrooms, laboratories, libraries, proper desks and chairs, library books and teaching aids.

5. Local governments continue to push to improve the quality of education personnel at the border. This can be done by involving teachers at the border in competency trainings and continuing to carry out routine supervision of the quality of teachers on Sebatik Island.

6. The TNI and Polri form communities and routinely educate people about defending the country, love for the country, nationalism, the history of national struggles and others.

7. The community carries out its role to continue to support the education delivery process and to supervise education delivery processes in border areas.

\section{Acknowledgements}

We would like to express our gratitude to Universitas Brawijaya, Indonesia and Universitas Muhammadiyah Makassar, Indonesia.

\section{References}

Abdi, M. I. (2018). The Implementation of Character Education in Kalimantan, Indonesia: Multi Site Studies.
Dinamika Ilmu, 18(2), 305321.

https://doi.org/10.21093/di.v 18i2.1289

Adler, A., \& Seligman, M. E. P. (2016). Using wellbeing for public policy: Theory, measurement, and recommendations. International Journal of Wellbeing, 6(1), 1-35. https://doi.org/10.5502/ijw.v $6 \mathrm{i} 1.429$

Agung, I. (2012). Kajian penyelenggaraan pendidikan di daerah perbatasan. Jurnal Ilmiah VISI P2TK PAUD NI, 7(2), 173-184.

Asri, S. (2016). Pendidikan Di Wilayah Perbatasan ( Equity and Improvement Policy of Education Quality in Border Area ). Balitbangda Kalimantan Timur, 25-43.

Gronberg, T. J., Jansen, D. W., \& Taylor, L. L. (2011). The impact of facilities on the cost of education. National Tax Journal, 64(1), 193-218. https://doi.org/10.17310/ntj. 2011.1.08

Indonesia, B. P. S. R. (2018). Statistik Indonesia 2018. Jakarta: Badan Pusat Statistik Republik Indonesia.

Joshua, S., Ibietan, J., \& Azuh, D. (2016). Education and Nigeria'S National Security. INTED2016 Proceedings, 1(April 2017), 3660-3665. https://doi.org/10.21125/inte d.2016.1883

Kurniawan, R., \& Managi, S. (2018). Economic Growth and Sustainable Development in Indonesia: An Assessment. Bulletin of Indonesian Economic Studies, 54(3), 339361.

https://doi.org/10.1080/0007 4918.2018.1450962 
Lambert, K., \& Penney, D. (2020). Curriculum interpretation and policy enactment in health and physical education: researching teacher educators as policy actors. Sport, Education and Society, 25(4), 378-394.

https://doi.org/10.1080/1357 3322.2019.1613636

Miles, M. B., \& Huberman, A. M. (2007). Analisis Data Kualitatif: Buku Sumber Tentang Metode-Metode Baru. Jakarta: Universitas Indonesia Press.

Mujahidun. (2016). Pemerataan Pendidikan Anak Bangsa: Pendidikan Gratis Versus Kapitalisme Pendidikan. Tarbiyatuna, 7(1), 38-52.

Rani, F. (2012). Strategi Pemerintah Indonesia Dalam Meningkatkan Keamanan Wilayah Perbatasan Menurut Perspektif Sosial Pembangunan. Jurnal Transnasional, 4(1), 1-17.

Rantau Itasari, E. (2020). BORDER MANAGEMENT BETWEEN INDONESIA AND MALAYSIA IN INCREASING THE ECONOMY IN BOTH BORDER AREAS. Jurnal Komunikasi Hukum (JKH), $\quad 6(1), \quad 219$. https://doi.org/10.23887/jkh. v6i1.23473

Ro, J. (2020). Curriculum, standards and professionalisation: The policy discourse on teacher professionalism in Singapore. Teaching and Teacher Education, 91, 103056. https://doi.org/10.1016/j.tate .2020 .103056

Rosliana, L., W, F. H., Lutfie, W., Hidayah, K., \& Aziza, T. N. (2015). Manajemen

Perbatasan Fokus Inovasi Pendidikan di Perbatasan
Kalimantan Utara. Jurnal Borneo Administrator, 11(3), 316-339.

Sabatier, P. A. (1986). Top-Down and Bottom-Up Approaches to Implementation Research: A Critical Analysis and Suggested Synthesis. Journal of Public Policy, 6(1), 21-48. https://doi.org/10.1017/S014 3814 X00003846

Siregar, C. N. (2008). Analisis Potensi Daerah Pulau-Pulau Terpencil Dalam Rangka Meningkatkan Ketahanan, Keamanan Nasional, Dan Keutuhan Wilayah Nkri Di Nunukanâkalimantan Timur. Jurnal Sosioteknologi, 7(13), 345-368-368.

Suciati, \& Ariningsih. (2016). Pengembangan Model Pendidikan Menengah "Sekolah Kebangsaan" di Daerah Terpencil, Tertinggal, Terluar dan Perbatasan sebagai Implementasi Pembelajaran PKn. Jurnal Moral Kemasyarakatan, 1(1), 76-86.

Uline, C., \& Tschannen-Moran, M. (2008). The walls speak: The interplay of quality facilities, school climate, and student achievement. Journal of Educational Administration, 46(1), $\quad 55-73$. https://doi.org/10.1108/0957 8230810849817

Yanti \& Nini. (2018). Menyoroti Sejarah Perjuangan Bangsa Dalam Meningkatkan Nasionalisme Siswa Pendidikan Dasar Di Daerah Perbatasan Kalimantan Barat Dan Kalimantan Utara. Prosiding Kolokium Doktor Dan Seminar Hasil Penelitian Hibah, 1, 296-305. 
(C) 2021 by the Authors. Submitted for possible open access publication under the terms and conditions of the Creative Commons Attribution (CC BY SA) license (https://creativecommons.org/licenses/by-sa/3.0/). 